\title{
Genetic structure of the giant kelp Macrocystis pyrifera along the southeastern Pacific
}

\author{
E. C. Macaya ${ }^{1,2, *}$, G. C. Zuccarello ${ }^{1}$ \\ ${ }^{1}$ School of Biological Sciences, Victoria University of Wellington, PO Box 600, Wellington, New Zealand \\ ${ }^{2}$ Present address: Departamento de Oceanografía, Facultad de Ciencias Naturales y Oceanográficas, Universidad de \\ Concepción, Casilla 160-C, Concepción, Chile
}

\begin{abstract}
We assessed the genetic structure of the giant kelp Macrocystis pyrifera across a broad latitudinal range along the southeastern Pacific coast (SEP). Specifically we analyzed the concordance of putative biogeographic breaks with genetic discontinuities and the effect of historical and contemporary events on the genetic pattern of this important seaweed. Mitochondrial DNA and single-strand DNA conformation polymorphism (SSCP) analysis for a total of 730 samples were carried out. Only 5 haplotypes were found among individuals collected along $4800 \mathrm{~km}$ of coastline, with very low haplotype diversity and a shallow genealogy compared with other macroalgal species. Some phylogeographic disjunctions in $M$. pyrifera were found to correspond roughly to established biogeographic breaks. On the southern coast we found a genetic break at $42^{\circ} \mathrm{S}$ (Chiloé Island) coincident with a well-known biogeographic boundary, while the genetic break found between samples in central/northern Chile $\left(33^{\circ} \mathrm{S}\right)$ does not correspond to any known biogeographic breaks in other brown algae, but does reflect a break associated with other marine taxa. The low genetic diversity in northern Chile may be related to contemporary events (e.g. El Niño Southern Oscillation) while in southern Chile the haplotype distribution may reflect the effect of historical events (Last Glacial Maximum; LGM). Additionally, we compared the SEP data with samples from some of the subantarctic islands and New Zealand. The results showed shared haplotypes among some of the subantarctic islands and southern-central Chile, suggesting a recent colonization of the subantarctic region. The high dispersal potential of kelp rafts may also help to explain the low genetic diversity observed. We conclude that both present and historic events are responsible for the genetic structure of $M$. pyrifera along the SEP.
\end{abstract}

KEY WORDS: Dispersal $\cdot$ Biogeography $\cdot$ ENSO $\cdot$ Kelp $\cdot$ Macrocystis pyrifera $\cdot$ Mitochondrial DNA Phylogeography $\cdot$ Southeastern Pacific $\cdot$ Subantarctic

\section{INTRODUCTION}

Biogeographic regions are generally delimited by discontinuities between biotic assemblages, and may be derived from both historical (e.g. glaciations) and/or contemporary (e.g. oceanographic) processes (Riginos \& Nachman 2001). Along the southeastern Pacific coast of Peru and Chile (hereafter SEP) the boundaries of biogeographic regions have long been discussed (e.g. Brattström \& Johanssen 1983, Lancellotti \& Vásquez 1999, Santelices \& Meneses 2000, Camus 2001, Vidal et al. 2008). Most biogeographic studies have proposed 2 main biogeographic regions: the Peruvian or warm-temperate province (between 6 and $30^{\circ} \mathrm{S}$ ) and the Magellan or cold-temperate province (between 40 or $42^{\circ} \mathrm{S}$ and $56^{\circ} \mathrm{S}$ ); additionally, several authors have recognized an intermediate area between 30 and $33^{\circ} \mathrm{S}$ and 40 and $42^{\circ} \mathrm{S}$ made of mixed components from the 2 neighboring regions (e.g. Brattström \& Johanssen 1983) (Fig. 1). The distribution of algal species along the SEP has also shown geographic breaks in species composition (Santelices 1980, Meneses \& Santelices 2000, Santelices \& Meneses 2000). Two main breaks have been reported: one at 


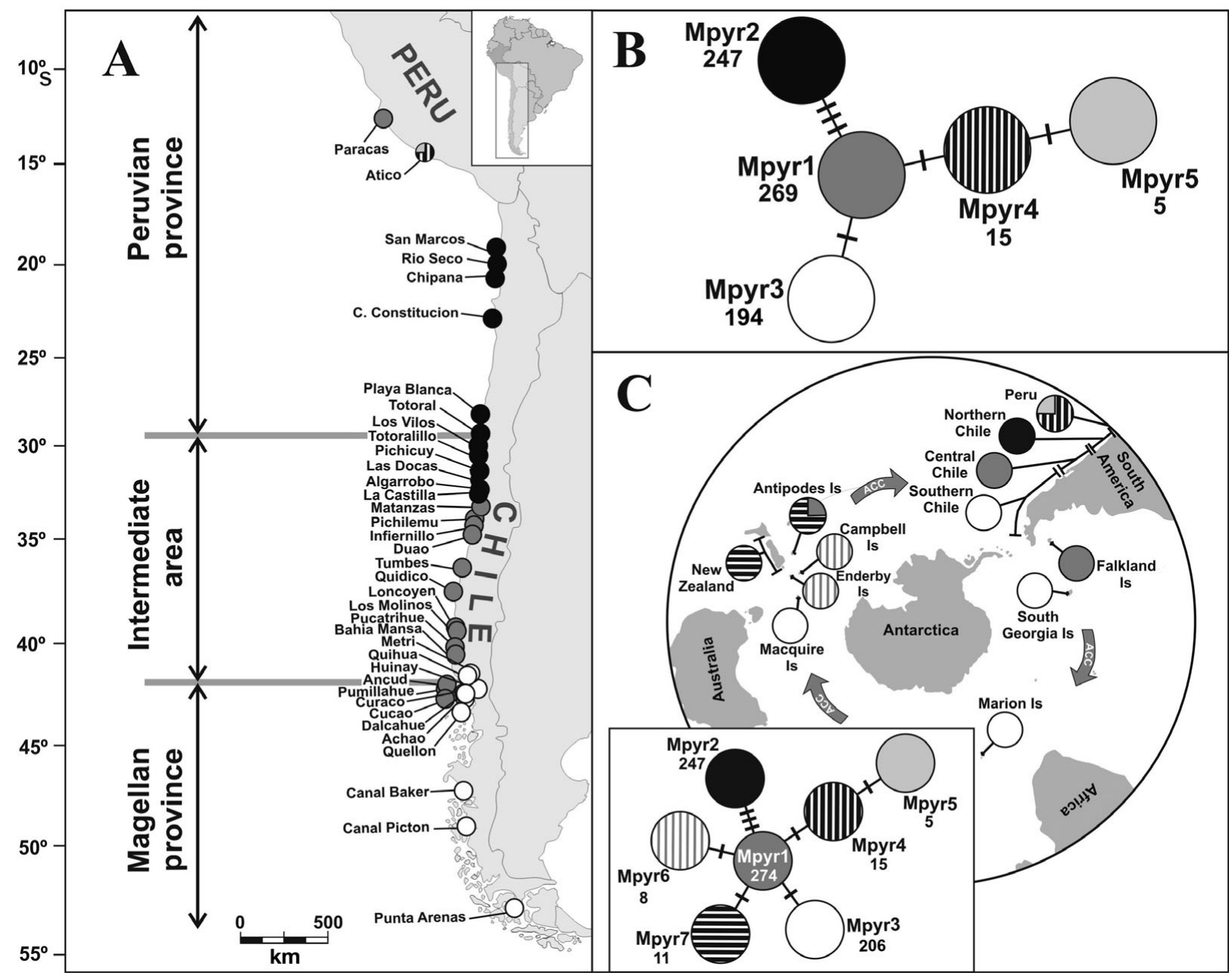

Fig. 1. (A) Southeastern Pacific coast (SEP) showing the location of collecting sites. Different shading represents different haplotypes. For detailed descriptions of sites see Table 1. Map also shows the 3 biogeographic provinces reported for SEP: Peruvian province, Intermediate area, and Magellan province. Grey lines represent the biogeographic breaks at 30 and $42^{\circ} \mathrm{S}$. (B) Statistical parsimony network of all sampled populations from SEP, connecting lines shows mutational pathways among haplotypes, and small lines represent single-site substitutions. (C) Haplotype distribution including samples from subantarctic islands and New Zealand. The frequency of each haplotype is shown below each haplotype for (B) and (C). ACC: Antarctic Circumpolar Current

$30^{\circ} \mathrm{S}$ is explained by the prevailing oceanographic conditions, resultant of upwelling events (Meneses \& Santelices 2000, Santelices \& Meneses 2000) and shows marked discontinuity especially in brown algae (Meneses \& Santelices 2000). The second major break is located at 40 to $42^{\circ} \mathrm{S}$, which has also been reported for several marine organisms (Brattström \& Johanssen 1983, Fernández et al. 2000, Camus 2001, Thiel et al. 2007) and has been explained by changed water conditions (lower salinity, less wave exposure) (Meneses \& Santelices 2000), topographical breakup of the coastline caused by the increased number of fjords from which large amounts of freshwater enter the sea (Lancellotti \& Vásquez 1999), and divergence of the main oceanographic currents (Cárdenas et al. 2009).
Species with high dispersal potential would theoretically be expected to show limited genetic disjunctions associated with biogeographic breaks (Thiel et al. 2007), and, indeed, high levels of gene flow along the SEP have been reported for several marine taxa. Using allozymes and amplified fragment length polymorphisms, Gomez-Uchida et al. (2003) reported genetic homogeneity over $2500 \mathrm{~km}$ of the Chilean coast for the hairy edible crab Cancer setosus, which the authors attributed to its long-lived planktonic larval stage $(60 \mathrm{~d})$. Similar lack of genetic structure along major parts of the Chilean coast has been reported for the Chilean abalone Concholepas concholepas (Gallardo \& Carrasco 1996, Cárdenas et al. 2009), the blue mussel Mytilus chilensis (Toro et al. 
2006), and the pelagic fish Merluccius gayi (Galleguillos et al. 2000).

In contrast to these zoological species, marine macroalgae are less explored. To date, only 1 study has addressed concordance between phylogeographic patterns and the 2 main biogeographic transitions along the SEP. Tellier et al. (2009) found a major phylogeographic break at $30^{\circ} \mathrm{S}$ in the intertidal kelp Lessonia nigrescens, a brown alga with reduced gene flow (Martínez et al. 2003, Faugeron et al. 2005) and no floating structures that could facilitate dispersal of adult thalli. We may expect a different result in kelps with high dispersal potential, such as Macrocystis pyrifera. The dispersal of this alga can be achieved by microscopic spores (zoospores) or by transport of large sporophytes that become dislodged and set adrift (Reed et al. 2006). The dispersal capacity of kelp spores is restricted, and they are rarely transported effectively over distances exceeding a few meters (Anderson \& North 1966, Dayton 1973). Long-distance dispersal has been suggested for $M$. pyrifera zoospores by Reed et al. (2004, 2006); however, recent evidence suggests that floating adult kelp are more likely to be important in long-distance dispersal (Macaya et al. 2005, Hernández-Carmona et al. 2006). Along the Chilean coast, Macaya et al. (2005) determined that $27 \%$ of floating M. pyrifera rafts possessed functional reproductive blades (i.e. viable spores released), and it was estimated that fertility could be maintained for at least $21 \mathrm{~d}$. Spore dispersal from kelp rafts may play a valuable role in long-distance dispersal events that are important for biogeographic expansion and genetic exchange (Reed et al. 2006). This would suggest substantial inter-population genetic homogeneity in $M$. pyrifera. Using ITS sequences, Coyer et al. (2001) found little genetic differentiation in samples collected across a wide geographic range (Chile, South Africa, Marion Island, Tasmania, Australia, and New Zealand). Specifically, along the SEP these authors looked at only 5 samples collected from southern Chile: Punta Pucatrihue $(n=1)$ and Metri Bay ( $\mathrm{n}=4$ ) (40 to $41^{\circ} \mathrm{S}$, respectively) separated only by $200 \mathrm{~km}$. Similarly, a recent study by Macaya \& Zuccarello (2010), has analyzed mitochondrial cytochrome c oxidase subunit I (COI) sequences globally including few (7) sites along the SEP. Although their goal was focused on taxonomic issues, they did note low genetic structure and shared haplotypes among distant areas from the southern hemisphere (Macaya \& Zuccarello 2010). An extensive sampling along the SEP is required to have a better understanding of the genetic pattern in this area.

During the Last Glacial Maximum (LGM; 18000 to 20000 yr ago), ice sheets covered broad areas of southern Chile from 35 to $54^{\circ} \mathrm{S}$ (McCulloch et al. 2000, Hulton et al. 2002) including the whole of the Chilean fjords (Fig. 2). The impact of glaciations on the distribution and genetic variation of species in southern Chile has been documented, but mostly for terrestrial (Muellner et al. 2004, Marchelli \& Gallo 2006, Himes et al. 2008, Rodriguez-Serrano et al. 2008, Victoriano et al. 2008) or freshwater biota (Ruzzante et al. 2008, Zemlak et al. 2008, 2010, Xu et al. 2009). A recent colonization, after the LGM and the retreat of sea ice, of Durvillaea antarctica in the subantarctic region by a series of long-distance rafting events has been suggested (Fraser et al. 2009). A recent article described the effect of the most recent ice age on the genetic imprints patterns of D. antarctica at the Chilean Patagonia (Fraser et al. 2010); COI and rbc sequences revealed genetic homogeneity on this area and suggested a possible recolonization from transoceanic sources for this intertidal kelp. Studies on additional species will determine whether the effect of the LGM is a common feature in structuring genetic diversity among marine algae in this area.

Events such as the El Niño Southern Oscillation (ENSO) produce massive mortality of kelp in the Peruvian province and the northern part of the Intermediate area (Vega et al. 2005, Vasquez et al. 2006, Thiel et al. 2007). Such sharp population declines, or bottlenecks, such as those seen during recent ENSO events, may translate into losses of genetic variation of marine organisms (Steinfartz et al. 2007). Martínez et al. (2003) found that, in sites in northern and central Chile impacted by the 1982-83 ENSO, genetic diversity of Lessonia nigrescens was lower than in non-impacted sites.

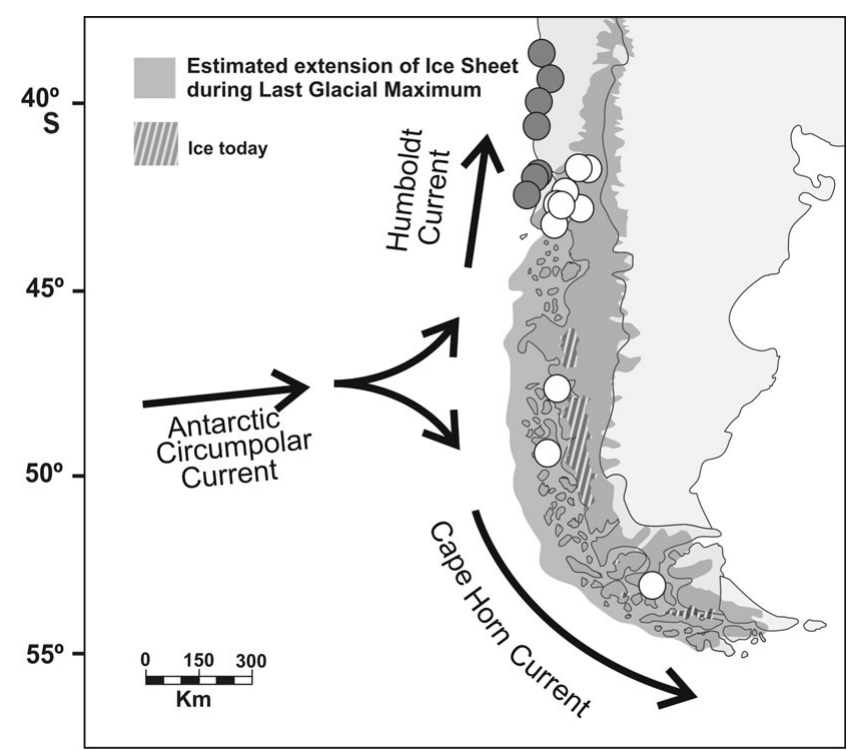

Fig. 2. Distribution of haplotypes in southern Chile showing the extent of the Last Glacial Maximum (LGM) ice sheet over the Chilean fjords and the distribution of existing icefields. Arrows show directions of major currents in southern Chile. For sampling locations details, see Fig. 1 and Table 1 
Macrocystis pyrifera is the largest seaweed on earth (up to 40 to $50 \mathrm{~m}$ long) and the most widely distributed kelp species, forming extensive submarine forests that harbor a rich diversity of marine life (Neushul 1971, North 1994). M. pyrifera also provides a valuable economic resource used for alginates, as food for abalone aquaculture, organic fertilizer, and recently as novel seafood (Hernández-Carmona et al. 1998, Gutierrez et al. 2006, Graham et al. 2007, Vásquez 2008). Along the SEP M. pyrifera distribution encompasses all 3 biogeographic provinces. It is present in areas both affected or unaffected by the ENSO phenomenon, and represents an important economic resource in Peru and Chile, though recent evidence suggests that it is over exploited (Vásquez 2008). Knowledge of genetic diversity and phylogeographic patterns will aid in the application of management and conservation policies, and can also provide insights into the ecological and evolutionary processes driving the distribution of marine macroalgae along the SEP. The aim of this study was to: (1) analyze the genetic diversity of $M$. pyrifera over a wide latitudinal range $\left(13\right.$ to $\left.53^{\circ} \mathrm{S}\right)$ along the SEP using mitochondrial DNA sequences; (2) evaluate the possible coincidence of phylogeographic breaks in this species with known biogeographic breaks; (3) evaluate whether the genetic diversity of this alga could be related to historical or contemporary events affecting the SEP (e.g. LGM and ENSO), and (4) compare the results with additional samples collected from New Zealand and some subantarctic islands.

\section{MATERIALS AND METHODS}

Sampling sites and collection. A total of 730 samples of Macrocystis pyrifera was collected between 2006 and 2009 from 39 sites between 13 and $53^{\circ} \mathrm{S}$, covering almost the entire geographical range of the species along the SEP (Fig. 1A-C, Table 1). At each site, multiple individuals ( 7 to 20 ) were collected haphazardly in an area of at least $200 \mathrm{~m}^{2}$. Healthy apical tips (2 to $3 \mathrm{~cm}^{2}$ ) without obvious epiphytes or epibionts were excised and preserved in Ziplock bags with silica gel until DNA extraction. Additionally, 40 samples from the subantarctic region and New Zealand were included in the analysis (Table 1).

DNA extraction and atp8-S amplification. DNA was extracted following the modified $1 \% \mathrm{~N}$-cetyl N,N,Ntrimethylammonium bromide (CTAB) method described by Zuccarello \& Lokhorst (2005). The mitochondrial intergenic spacer region between genes atp8 and trnS (atp8-S) was amplified using the primers atp8-trnS-F and atp8-trnS-R (Voisin et al. 2005). This region has been used for phylogeographic studies in several kelp species (e.g. Muraoka \& Saitoh 2005,
Voisin et al. 2005, Uwai et al. 2006, Tellier et al. 2009), and it has been suggested that this marker is a useful tool for phylogeographic studies in brown seaweeds (Engel et al. 2008).

PCR amplifications were performed following Voisin et al. (2005). Due to the large number of samples, single-stranded DNA conformation polymorphism (SSCP) analysis was carried out. SSCP allows discrimination between DNA fragments of the same size that are different in their nucleotide sequence (Sunnucks et al. 2000). Three $\mu$ l of PCR product was mixed with $9 \mu \mathrm{l} 95 \%$ formamide, $0.1 \%$ aqueous bromophenol blue/xylene cyanol, and 10mM NaOH, subsequently denatured at $95^{\circ} \mathrm{C}$ for $5 \mathrm{~min}$, then snap cooled on ice before loading. Gels contained 20\% 37.5:1 acrylamide/bis-acrylamide (Sigma Aldrich), 0.5× TBE buffer, $0.5 \%$ ammonium persulphate, $0.05 \%$ tetramethylethylenediamine (TEMED). Electrophoresis was carried out for 14 to $16 \mathrm{~h}$ at $4 \mathrm{~W}$ in $0.5 \times$ TBE buffer at $4^{\circ} \mathrm{C}$ on $225 \mathrm{~mm}$ long and $0.75 \mathrm{~mm}$ thick gels (BioRad). After electrophoresis, gels were silver stained following Bassam et al. (1991), and banding patterns were assigned by eye. To check the accuracy of SSCP typing, 3 to 4 individuals for each location were sequenced in both directions (Macrogen). One or more of each haplotype indicated by SSCP were sequenced from each sampling site. No ambiguous SSCP profiles were found, and each one has the same unique sequence.

Data analysis. Haplotype frequencies were calculated using DnaSP version 5.10 (Rozas \& Rozas 1995). Sequences were aligned using ClustalW in the BIOEDIT program (Hall 1999). Estimates of haplotype $(\mathrm{He})$ and nucleotide $(\pi)$ diversity were calculated for each population and for the entire dataset using ARLEQUIN V. 3.1 (Excoffier et al. 2005).

An unrooted statistical parsimony network was reconstructed using TCS 1.21 (Clement et al. 2000). Because of the lack of variation within populations and the low numbers of haplotypes, further analysis of genetic variation was not undertaken.

\section{RESULTS}

A region of $133 \mathrm{bp}$ was compared among 730 samples of Macrocystis pyrifera, collected from 38 sampling locations along the SEP. Each SSCP profile was found to have the same unique sequence, while some differed by only 1 base pair. Despite the large geographic area analyzed only 5 haplotypes were found, distinguished by only 6 variable sites (Fig. 1) (GenBank Accession no. HQ336480 to HQ336486). Haplotype Mpyr1 was the most common, present in $36.85 \%$ of the samples, followed by the haplotypes Mpyr2 and 
Table 1. Macrocystis pyrifera. Sampling sites along the southeastern Pacific coast (SEP), collection details and haplotype frequency. Mpyr indicates different haplotype number (see Fig. 1 for details)

\begin{tabular}{|c|c|c|c|c|}
\hline Region - sampling site & Coordinates & Collector & Sample size & Haplotype frequency \\
\hline \multicolumn{5}{|l|}{ SEP } \\
\hline Paracas & $13^{\circ} 55^{\prime} \mathrm{S}, 73^{\circ} 23^{\prime} \mathrm{W}$ & Alejandro Perez-Matus & 20 & Mpyr1 = 1.0 \\
\hline Atico & $15^{\circ} 58^{\prime} \mathrm{S}, 74^{\circ} 02^{\prime} \mathrm{W}$ & Alex Gamarra & 20 & Mpyr4 $=0.74$, Mpyr5 $=0.26$ \\
\hline San Marcos & $21^{\circ} 00^{\prime} \mathrm{S}, 70^{\circ} 09^{\prime} \mathrm{W}$ & Erasmo Macaya & 20 & Mpyr2 $=1.0$ \\
\hline Rio Seco & $21^{\circ} 06^{\prime} \mathrm{S}, 70^{\circ} 07^{\prime} \mathrm{W}$ & Erasmo Macaya & 20 & Mpyr2 $=1.0$ \\
\hline Chipana & $21^{\circ} 20^{\prime} \mathrm{S}, 70^{\circ} 05^{\prime} \mathrm{W}$ & Erasmo Macaya & 20 & Mpyr2 $=1.0$ \\
\hline Caleta Constitucion & $23^{\circ} 25^{\prime} \mathrm{S}, 70^{\circ} 35^{\prime} \mathrm{W}$ & Erasmo Macaya & 20 & Mpyr2 = 1.0 \\
\hline Playa Blanca & $28^{\circ} 11^{\prime} \mathrm{S}, 71^{\circ} 09^{\prime} \mathrm{W}$ & Ivan Hinojosa, Martin Thiel & 20 & Mpyr2 = 1.0 \\
\hline Punta Choros & $29^{\circ} 15^{\prime} \mathrm{S}, 71^{\circ} 28^{\prime} \mathrm{W}$ & Luciano Hiriart & 20 & Mpyr2 = 1.0 \\
\hline Totoral & $30^{\circ} 21^{\prime} \mathrm{S}, 71^{\circ} 40^{\prime} \mathrm{W}$ & Marcelo Valdebenito & 20 & Mpyr2 = 1.0 \\
\hline Los Vilos & $31^{\circ} 55^{\prime} \mathrm{S}, 71^{\circ} 31^{\prime} \mathrm{W}$ & Erasmo Macaya & 20 & Mpyr2 = 1.0 \\
\hline Totoralillo & $32^{\circ} 01^{\prime} \mathrm{S}, 71^{\circ} 30^{\prime} \mathrm{W}$ & Erasmo Macaya & 20 & Mpyr2 = 1.0 \\
\hline Pichicuy & $32^{\circ} 20^{\prime} \mathrm{S}, 71^{\circ} 27^{\prime} \mathrm{W}$ & Alonso Vega & 20 & Mpyr2 = 1.0 \\
\hline Las Docas & $32^{\circ} 08^{\prime} \mathrm{S}, 71^{\circ} 42^{\prime} \mathrm{W}$ & Claudio Saez & 7 & Mpyr2 = 1.0 \\
\hline Algarrobo & $33^{\circ} 21^{\prime} \mathrm{S}, 71^{\circ} 40^{\prime} \mathrm{W}$ & Erasmo Macaya & 20 & Mpyr2 = 1.0 \\
\hline La Castilla & $33^{\circ} 27^{\prime} \mathrm{S}, 71^{\circ} 40^{\prime} \mathrm{W}$ & Erasmo Macaya & 20 & Mpyr2 $=1.0$ \\
\hline Matanzas & $33^{\circ} 56^{\prime} \mathrm{S}, 71^{\circ} 52^{\prime} \mathrm{W}$ & Erasmo Macaya & 20 & Mpyr1 $=1.0$ \\
\hline Pichilemu & $34^{\circ} 22^{\prime} \mathrm{S}, 72^{\circ} 01^{\prime} \mathrm{W}$ & Erasmo Macaya & 20 & Mpyr1 $=1.0$ \\
\hline Infiernillo & $34^{\circ} 23^{\prime} \mathrm{S}, 72^{\circ} 01^{\prime} \mathrm{W}$ & Erasmo Macaya & 20 & Mpyr1 = 1.0 \\
\hline Duao & $34^{\circ} 53^{\prime} \mathrm{S}, 72^{\circ} 09^{\prime} \mathrm{W}$ & Ivan Hinojosa & 20 & Mpyr1 $=1.0$ \\
\hline Tumbes & $36^{\circ} 37^{\prime} \mathrm{S}, 73^{\circ} 05^{\prime} \mathrm{W}$ & Erasmo Macaya & 20 & Mpyr1 $=1.0$ \\
\hline Quidico & $37^{\circ} 22^{\prime} \mathrm{S}, 73^{\circ} 39^{\prime} \mathrm{W}$ & Ivan Hinojosa, Martin Thiel & 9 & Mpyr1 $=1.0$ \\
\hline Loncoyen & $39^{\circ} 49^{\prime} \mathrm{S}, 73^{\circ} 24^{\prime} \mathrm{W}$ & Ivan Hinojosa, Martin Thiel & 20 & Mpyr1 = 1.0 \\
\hline Los Molinos & $39^{\circ} 50^{\prime} \mathrm{S}, 73^{\circ} 24^{\prime} \mathrm{W}$ & Erasmo Macaya & 20 & Mpyr1 = 1.0 \\
\hline Pucatrihue & $40^{\circ} 32^{\prime} \mathrm{S}, 73^{\circ} 43^{\prime} \mathrm{W}$ & Alejandro Buschmann & 20 & Mpyr1 = 1.0 \\
\hline Bahia Mansa & $40^{\circ} 34^{\prime} \mathrm{S}, 73^{\circ} 44^{\prime} \mathrm{W}$ & Erasmo Macaya & 20 & Mpyr3 = 1.0 \\
\hline Metri & $41^{\circ} 36^{\prime} \mathrm{S}, 72^{\circ} 42^{\prime} \mathrm{W}$ & Alejandro Buschmann & 20 & Mpyr2 $=1.0$ \\
\hline Quihua & $41^{\circ} 36^{\prime} \mathrm{S}, 72^{\circ} 42^{\prime} \mathrm{W}$ & Ivan Hinojosa, Martin Thiel & 20 & Mpyr2 = 1.0 \\
\hline Ancud & $41^{\circ} 51^{\prime} \mathrm{S}, 73^{\circ} 49^{\prime} \mathrm{W}$ & Erasmo Macaya & 20 & Mpyr3 = 1.0 \\
\hline Pumillahue & $41^{\circ} 52^{\prime} \mathrm{S}, 74^{\circ} 00^{\prime} \mathrm{W}$ & Ivan Hinojosa, Martin Thiel & 20 & Mpyr3 = 1.0 \\
\hline Quemchi & $42^{\circ} 08^{\prime} \mathrm{S}, 73^{\circ} 28^{\prime} \mathrm{W}$ & Erasmo Macaya & 20 & Mpyr3 $=1.0$ \\
\hline Dalcahue & $42^{\circ} 22^{\prime} \mathrm{S}, 73^{\circ} 39^{\prime} \mathrm{W}$ & Erasmo Macaya & 7 & Mpyr3 = 1.0 \\
\hline Huinay & $42^{\circ} 22^{\prime} \mathrm{S}, 72^{\circ} 24^{\prime} \mathrm{W}$ & Ivan Hinojosa, Martin Thiel & 7 & Mpyr3 = 1.0 \\
\hline Curaco & $41^{\circ} 26^{\prime} \mathrm{S}, 73^{\circ} 36^{\prime} \mathrm{W}$ & Ivan Hinojosa & 20 & Mpyr3 = 1.0 \\
\hline Achao & $42^{\circ} 28^{\prime} \mathrm{S}, 73^{\circ} 29^{\prime} \mathrm{W}$ & Erasmo Macaya & 20 & Mpyr3 = 1.0 \\
\hline Cucao & $42^{\circ} 40^{\prime} \mathrm{S}, 74^{\circ} 07^{\prime} \mathrm{W}$ & Ivan Hinojosa, Martin Thiel & 20 & Mpyr1 = 1.0 \\
\hline Quellon & $43^{\circ} 08^{\prime} \mathrm{S}, 73^{\circ} 36^{\prime} \mathrm{W}$ & Erasmo Macaya & 20 & Mpyr3 = 1.0 \\
\hline Canal Baker & $47^{\circ} 26^{\prime} \mathrm{S}, 74^{\circ} 10^{\prime} \mathrm{W}$ & Ivan Hinojosa & 20 & Mpyr3 = 1.0 \\
\hline Canal Picton & $50^{\circ} 08^{\prime} \mathrm{S}, 74^{\circ} 40^{\prime} \mathrm{W}$ & Ivan Hinojosa & 20 & Mpyr3 = 1.0 \\
\hline Punta Arenas & $53^{\circ} 28^{\prime} \mathrm{S}, 70^{\circ} 51^{\prime} \mathrm{W}$ & Andres Mansilla & 20 & Mpyr3 = 1.0 \\
\hline \multicolumn{5}{|l|}{ Subantarctic region } \\
\hline Marion Island & $46^{\circ} 50^{\prime} \mathrm{S}, 37^{\circ} 50^{\prime} \mathrm{E}$ & Ceridwen Fraser & 4 & Mpyr3 = 1.0 \\
\hline Antipodes Island & $49^{\circ} 40^{\prime} \mathrm{S}, 178^{\circ} 48^{\prime} \mathrm{E}$ & Ceridwen Fraser & 4 & Mpyr7 $=0.75$, Mpyr1 $=0.25$ \\
\hline Campbell Island & $52^{\circ} 32^{\prime} \mathrm{S}, 169^{\circ} 11^{\prime} \mathrm{E}$ & Ceridwen Fraser & 4 & Mpyr6 = 1.0 \\
\hline Enderby Island & $50^{\circ} 37^{\prime} \mathrm{S}, 166^{\circ} 15^{\prime} \mathrm{E}$ & Ceridwen Fraser & 4 & Mpyr6 = 1.0 \\
\hline Falkland Islands & $51^{\circ} 37^{\prime} \mathrm{S}, 57^{\circ} 45^{\prime} \mathrm{W}$ & Joost Pompert & 4 & Mpyr1 $=1.0$ \\
\hline South Georgia Island & $54^{\circ} 17^{\prime} \mathrm{S}, 36^{\circ} 29^{\prime} \mathrm{W}$ & Anjali Pade & 4 & Mpyr3 $=1.0$ \\
\hline Macquarie Island & $54^{\circ} 38^{\prime} \mathrm{S}, 158^{\circ} 48^{\prime} \mathrm{E}$ & Annelise Wiebkin & 4 & Mpyr3 = 1.0 \\
\hline \multicolumn{5}{|l|}{ New Zealand } \\
\hline Kau Bay & $41^{\circ} 17^{\prime} \mathrm{S}, 174^{\circ} 49^{\prime} \mathrm{E}$ & Erasmo Macaya & 4 & Mpyr7 $=1.0$ \\
\hline Fiordland & $45^{\circ} 16^{\prime} \mathrm{S}, 166^{\circ} 50^{\prime} \mathrm{E}$ & Wendy Nelson & 4 & Mpyr7 $=1.0$ \\
\hline Stewart Island & $46^{\circ} 53^{\prime} \mathrm{S}, 168^{\circ} 07^{\prime} \mathrm{E}$ & Erasmo Macaya & 4 & Mpyr7 $=1.0$ \\
\hline
\end{tabular}

Mpyr3, present in 33.84 and $26.58 \%$ of the samples, respectively, while haplotypes Mpyr4 and Mpyr5 were detected in only $2.73 \%$ of samples. Haplotypes corresponded to particular geographic areas, with Mpyr2 ranging from San Marcos $\left(21^{\circ} \mathrm{S}\right)$ to Algarrobo $\left(33^{\circ} \mathrm{S}\right)$, Mpyr1 from Matanzas $\left(33^{\circ} \mathrm{S}\right)$ to Cucao $\left(42^{\circ} \mathrm{S}\right)$, Mpyr3 from Metri $\left(41^{\circ} \mathrm{S}\right)$ to Punta Arenas $\left(53^{\circ} \mathrm{S}\right)$, and haplotypes Mpyr4 and Mpyr5 restricted to Atico, Peru (15 $\mathrm{S})$ (Fig. 1). Interestingly, the most northern sampling site, Paracas, Peru $\left(13^{\circ} \mathrm{S}\right)$, displayed the same haplotype as central Chile (Mpyr1). At each sampling site only 1 haplotype was detected, with the exception of Atico, 
where haplotypes Mpyr4 and Mpyr5 were both found (Fig.1, Table 1).

Haplotype diversity for all SEP samples was 0.7561 $( \pm 0.013 \mathrm{SD})$, and nucleotide diversity was 0.01563 $( \pm 0.00056 \mathrm{SD})$. The statistical parsimony network, which indicates the relationships among haplotypes with a $95 \%$ connection limit (Fig. 1B) resulted with Mpyr1 as a central haplotype, separated only by 1 substitution from haplotypes Mpyr3 and Mpyr4, and by 3 substitutions from haplotype Mpyr2.

At $30^{\circ} \mathrm{S}$ no sign of a phylogeographic break was observed. At $42^{\circ} \mathrm{S}$ we found an overlap of 2 haplotypes, Mpyr1 and Mpyr3. Both of these Chiloe Island haplotypes had different distributions, with haplotype Mpyr1 restricted to the west side of the island, whereas haplotype Mpyr3 was found only on the east side (Fig. 2).

The comparison of the SEP Macrocystis pyrifera data with data from some of the subantarctic islands and New Zealand (Fig. 1C) revealed a shared Mpyr3 haplotype between southern Chile and 3 subantarctic islands: South Georgia, Marion, and Macquarie. Haplotype Mpyr1 was shared among Central Chile, the Falklands, and the Antipodes. Additionally, 2 new haplotypes were found: Mp6 from the islands Campbell and Enderby, and Mpyr7 from New Zealand and the Antipodes. The haplotype network showed a starlike shape with haplotypes Mpyr6 and Mpyr7 separated by only 1 base pair from the central haplotype Mpyr1.

\section{DISCUSSION}

Our study showed fairly low genetic variation among atp8-S sequences of Macrocystis pyrifera along the SEP. The limited phylogeographic structure detected does, nonetheless, reveal an intriguing pattern that is likely the result of both contemporary and historical events.

Two distinct genetic breaks were observed along the $\mathrm{SEP}$; their relation to putative biogeographic barriers is discussed in 'Concordance of biogeographic and phylogeographic breaks'. Comparison with samples from subantarctic islands and New Zealand revealed that these localities shared haplotypes with central and southern Chile, suggesting a recent colonization after the LGM in some locations of the subantarctic region probably from central Chile.

\section{Genetic diversity and dispersal potential}

Our data showed low levels of genetic diversity in Macrocystis pyrifera populations along the SEP. Haplotypes were distributed over very large geographic areas: haplotype Mpyr2 in northern Chile between 21 and $33^{\circ} \mathrm{S},(\sim 1500 \mathrm{~km})$; haplotype Mpyr1 in central Chile between 33 and $42^{\circ} \mathrm{S}(\sim 1000 \mathrm{~km})$; and haplotype Mpyr3 in southern Chile between 41 and $53^{\circ} \mathrm{S}$ $(\sim 1400 \mathrm{~km})$. A similar low genetic variation has been shown in several marine species along the Chilean coast, both invertebrates (Gallardo \& Carrasco 1996, Toro \& Aguila 1996, Gallardo et al. 2003, GomezUchida et al. 2003, Toro et al. 2006) and fish (Galleguillos et al. 2000), presumably associated with the high dispersal potential of these taxa, which have long-lived larvae. Along the SEP, few studies have analyzed the genetic structure of macroalgae (Martínez et al. 2003, Faugeron et al. 2005, Vidal et al. 2008, Tellier et al. 2009), and most of them have found high genetic differentiation among populations. In contrast, we provide evidence for low genetic variation in a macroalga over a wide area of the SEP and throughout the subantarctic region.

The low genetic variation observed along the SEP could be the result of several factors. First, a recent colonization event or events; Macrocystis pyrifera is thought to have originated in the northern hemisphere and spread to the southern hemisphere reaching western South America recently $\left(10^{4}\right.$ to $3 \times 10^{6} \mathrm{yr}$ ago) (Coyer et al. 2001). This is supported by genetic evidence from ITS (Coyer et al. 2001) and mitochondrial COI sequences (Macaya \& Zuccarello 2010), where little divergence was found among samples collected across a wide geographic area of the southern hemisphere. Alternatively high levels of gene flow among populations may have a direct relationship with the high dispersal potential of $M$. pyrifera, especially given its ability to float once detached (Macaya et al. 2005, Hernández-Carmona et al. 2006). Continuous growth and production of viable zoospores from M. pyrifera rafts along the Chilean coast has been reported (Macaya et al. 2005). Similarly, rafting of storm-detached thalli of Fucus vesiculosus, which release gametes when deposited at a new site, has been proposed to lead to connectivity between populations (Muhlin et al. 2008), and dispersal by floating thalli has been suggested for other macroalgal species (e.g., Dayton 1973, van den Hoek 1987, Buschmann et al. 2006, McKenzie \& Bellgrove 2008, Fraser et al. 2009, Buchanan \& Zuccarello in press, and see review by Thiel \& Gutow 2005).

\section{Concordance of biogeographic and phylogeographic breaks}

Along the SEP, genetic disjunctions in Macrocystis pyrifera corresponded roughly to previously described biogeographic breaks (30 and $\left.42^{\circ} \mathrm{S}\right)$. Haplotypes Mpyr2, Mpyr1, and Mpyr3 were largely restricted to the Peruvian province, Intermediate, and Magellan 
provinces described for the SEP, respectively (Fig. 1). However, the genetic disjunction between haplotypes Mpyr2 and Mpyr1 was somewhat further south than breaks observed in other taxa in this region, occurring in $M$. pyrifera at around $33^{\circ} \mathrm{S}$ rather than $30^{\circ} \mathrm{S}$. For the intertidal kelp Lessonia nigrescens, for example, a clear genetic break has been recently established at $30^{\circ} \mathrm{S}$ (Tellier et al. 2009), and the authors suggest the limited dispersal may have contributed to the maintenance of this genetic pattern. The presence of upwelling in this area is thought to be responsible for a biogeographic break in brown macroalgae (Santelices 1980, Meneses \& Santelices 2000). Although there is a clear phylogeographic break at $33^{\circ} \mathrm{S}$ for $M$. pyrifera, this break may be related to some environmental adaptation of Macrocystis 'ecomorphs' (Graham et al. 2007, Demes et al. 2009). In northern-central Chile, 2 different ecomorphs are present (Macaya \& Zuccarello 2010), haplotype Mpyr2 whose southern distribution limit is at $33^{\circ} \mathrm{S}$ represents samples of the $M$. integrifolia ecomorph, while the ecomorph $M$. pyrifera has its northern distributional limit at $33^{\circ} \mathrm{S}$. No overlap of haplotypes and ecomorphs was found. These ecomorphs are generally adapted to specific environments, $M$. integrifolia is generally found in shallow waters, whereas $M$. pyrifera is generally found in intermediate to deep waters (Graham et al. 2007). Studies on kelp physiology in different environments and on the role of the mitochondrial genome in potential adaptations to specific environments are needed (Tellier et al. 2009). Additionally the presence of unique haplotypes in Atico and the putative ancestral haplotype Mpyr1 in Paracas is intriguing, additional sampling along the Peruvian coast, and comparison with other areas (e.g. the northern hemisphere), plus analysis with more molecular markers are needed to understand variation from this low latitude.

At $42^{\circ} \mathrm{S}$ the phylogeographic break coincides with a primary biogeographic break previously suggested for the SEP (Camus 2001). The haplotype distribution at the contact area overlaps, with haplotype Mpyr1 distributed up to Cucao at $42^{\circ} \mathrm{S}$ and haplotype Mpyr3 beginning its distribution in Metri at $41^{\circ} \mathrm{S}$. The biogeographic break at 40 to $42^{\circ} \mathrm{S}$ has been explained mainly because of the topographical breakup of the coastline by fjords where large amount of fresh water enter the sea (Lancellotti \& Vásquez 1999) and the divergence of the main oceanic currents (Humboldt and Cape Horn; Fig. 2) (Cárdenas et al. 2009). Interestingly the haplotypes were locally separate on Chiloé Island, with haplotype Mp1 on the west coast and Mpyr3 on the east coast. This particular distribution of haplotypes may be related with the LGM (see 'Contemporary and historical events'). Similarly Fraser et al. (2010) suggested extirpation of Durvillaea antarctica populations during the last glacial period and described a postglacial recolonization in southern Chile (see 'Contemporary and historical events' below). Additional studies on other species may also show a similar pattern.

\section{Contemporary and historical events}

Along the area affected by ENSO ( 6 to $\left.30^{\circ} \mathrm{S}\right) 4$ haplotypes were found: 3 haplotypes in Peru and only 1 in northern central Chile. Local extinction of kelp populations during ENSO events is common in the area between 10 and $23^{\circ} \mathrm{S}$ (Camus 1990, Vasquez et al. 2006, Thiel et al. 2007). Reduced genetic variation in the kelp Lessonia nigrescens in 2 sites in northern Chile, Iquique $\left(20^{\circ} \mathrm{S}\right)$ and Antofagasta $\left(23^{\circ} \mathrm{S}\right)$, together with slow recolonization (<60 $\mathrm{km}$ in $20 \mathrm{yr}$ ) has been reported by Martínez et al. (2003). It is likely that Macrocystis pyrifera was similarly affected but more sampling from 10 to $20^{\circ} \mathrm{S}$ are needed to confirm this. On the other hand, rafting may be a very important dispersal mechanism for populations that suffer recurrent extinctions and recolonizations (Thiel et al. 2007). Along the SEP, kelp rafts may colonize following the northwards direction of the Humboldt Current much more quickly than in non-floating algae such as Lessonia nigrescens. Further research with more variable molecular markers (microsatellites) may reveal a more detailed genetic structure in populations affected by ENSO and may also determine the location of source populations.

The distribution of haplotype Mpyr3 in centralsouthern Chile corresponds precisely to the extent of the Patagonian ice sheet at the LGM (Fig. 2). This event had a major effect on the global distributions of species, with many taxa forced out of areas covered by encroaching ice sheets (Hewitt et al. 2003). The glaciations may have had massive effects on distribution, abundance, and productivity of Macrocystis pyrifera (Graham et al. 2007). The effect of the LGM on algal distribution and genetic structure has been studied mainly in the northern hemisphere (e.g. van Oppen et al. 1995, Provan et al. 2001, Gabrielsen et al. 2002, Coyer et al. 2003, Hoarau et al. 2007, Muhlin \& Brawley 2009), but recent research on phylogeographic structure in the southern hemisphere bull-kelp Durvillaea antarctica has shown that the species likely recolonised much of the subantarctic region following elimination by ice scour at the LGM (Fraser et al. 2009). Recent work has also confirmed this result (Fraser et al. 2010), with genetic homogeneity in D. antarctica collected south of $44^{\circ} \mathrm{S}$, they suggested recolonization from a transoceanic source because of the close genetic relation with samples from subantarctic islands and New Zealand. The comparison with $M$. pyrifera 
from the subantarctic region revealed a similar result, a shared haplotype (Mpyr3) along the area affected by LGM (see Fraser et al. 2009 for details). Furthermore, areas not affected by ice at the LGM (such as New Zealand, Antipodes Island, Campbell Island, and Enderby Island) displayed unique haplotypes closely related with the putative ancestral haplotype Mpyr1 (Fig. 1C). Antipodes Island and Falkland Island share haplotype with central Chile (Mpyr1) suggesting that Mpyr1 was probably widely present in the subantarctic region before the LGM. Similar to $D$. antarctica (Fraser et al. 2009, 2010) and fauna inhabiting their holdfasts (Nikula et al. 2010), the Antarctic Circumpolar Current may facilitate the recolonization after the LGM of $M$. pyrifera via detached kelp rafts. The recolonization of $M$. pyrifera in southern Chile therefore is similar to $D$. antarctica, although in $M$. pyrifera case only subantarctic islands shared the same haplotype.

\section{CONCLUSIONS}

Both contemporary and historic environmental factors are likely responsible for the genetic pattern of Macrocystis pyrifera in the SEP. Although sampling was extensive (over $4800 \mathrm{~km}$ ), only 5 haplotypes were found with few mutations separating them. The high dispersal potential and a recent colonization history may explain the genetic homogeneity in this area. Despite its dispersal potential, however, distinct phylogeographic breaks were evident and correspond roughly to known biogeographic breaks in other marine taxa. The low genetic diversity in low latitudes may be due to local extinctions of kelp bed populations due to ENSO effect. The presence of the ice sheet at the LGM has shaped the genetic features of $M$. pyrifera in southern Chile. Shared haplotypes among vast areas of the subantarctic region suggests recolonization via detached kelp rafts facilitated by the Antarctic Circumpolar Current. Our results contribute to the management of this ecologically and economically important kelp species. Kelp harvesting and aquaculture regulations must take into account the low genetic variation and the presence of exclusive haplotypes in vast areas of the SEP coast. Finally, further research using more variable molecular markers will be useful to detect and understand colonization routes, connectivity and the effect of anthropogenic disturbances.

Acknowledgements. We greatly appreciate the help of our colleagues (Table 1) for kindly providing algal material. Thanks to Ceridwen Fraser and 2 anonymous reviewers for comments on earlier versions of this manuscript. Funding was provided from Department of Conservation New Zealand, New Zealand Study Abroad Scholarship and CONICYTVUW PhD scholarship to E.C.M.

\section{LITERATURE CITED}

Anderson EK, North WJ (1966) In situ studies of spore production and dispersal in the giant kelp, Macrocystis. Proc Int Seaweed Symp 5:73-86

Bassam BJ, Caetano-Anollés G, Gresshoff PM (1991) Fast and sensitive silver staining of DNA in polyacrylamide gels. Anal Biochem 196:80-83

Brattström H, Johanssen A (1983) Ecological and regional zoogeography of the marine benthic fauna of Chile. Sarsia 68:289-339

Buchanan J, Zuccarello GC (in press) Decoupling of short and long distance dispersal pathways in the endemic New Zealand seaweed Carpophyllum maschalocarpum (Phaeophyceae, Fucales). J Phycol

> Buschmann AH, Moreno C, Vásquez JA, HernándezGonzález MC (2006) Reproduction strategies of Macrocystis pyrifera (Phaeophyta) in southern Chile: the importance of population dynamics. J Appl Phycol 18:575-582

Camus PA (1990) Procesos regionales y fitogeografía en el Pacífico suroriental: el efecto de 'El Niño-Oscilación del Sur'. Rev Chil Hist Nat 63:11-17

> Camus PA (2001) Marine biogeography of continental Chile. Rev Chil Hist Nat 74:587-617

> Cárdenas L, Castilla JC, Viard F (2009) A phylogeographical analysis across three biogeographical provinces of the south-eastern Pacific: the case of the marine gastropod Concholepas concholepas. J Biogeogr 36:969-981

> Clement M, Posada D, Crandall KA (2000) TCS: a computer program to estimate gene genealogies. Mol Ecol 9: $1657-1659$

> Coyer JA, Smith GJ, Andersen RA (2001) Evolution of Macrocystis spp. (Phaeophyceae) as determined by ITS1 and ITS2 sequences. J Phycol 37:574-585

Coyer JA, Peters AF, Stam WT, Olsen JL (2003) Post-ice age recolonization and differentiation of Fucus serratus L. (Phaeophyceae; Fucaceae) populations in northern Europe. Mol Ecol 12:1817-1829

> Dayton PK (1973) Dispersion, dispersal, and persistence of the annual intertidal alga, Postelsia palmaeformis Ruprecht. Ecology 54:433-438

Demes KD, Graham MH, Suskiewicz TS (2009) Phenotypic plasticity reconciles incongruous molecular and morphological taxonomies: the giant kelp, Macrocystis (Laminariales, Phaeophyceae), is a monospecific genus. J Phycol 45:1266-1269

Engel CR, Billard E, Voisin M, Viard F (2008) Conservation and polymorphism of mitochondrial intergenic sequences in brown algae (Phaeophyceae). Eur J Phycol 43:195-205

Excoffier L, Laval G, Schneider S (2005) Arlequin (version 3.0): an integrated software package for population genetics data analysis. Evol Bioinform 1:47-50

Faugeron S, Martinez EA, Correa JA, Billot C (2005) Longterm copper mine waste disposal in northern Chile associated with gene flow disruption of the intertidal kelp Lessonia nigrescens. Mar Ecol Prog Ser 288:129-140

> Fernández M, Jaramillo E, Marquet PA, Moreno CA and others (2000) Diversity, dynamics and biogeography of Chilean benthic nearshore ecosystems: an overview and guidelines for conservation. Rev Chil Hist Nat 73:797-830

> Fraser CI, Nikula R, Spencer HG, Waters JM (2009) Kelp genes reveal effects of subantarctic sea ice during the Last Glacial Maximum. Proc Natl Acad Sci USA 106: $3249-3253$

Fraser CI, Thiel M, Spencer H, Waters J (2010) Contemporary habitat discontinuity and historic glacial ice drive genetic divergence in Chilean kelp. BMC Evol Biol 10:203 
Gabrielsen TM, Brochmann C, Rueness J (2002) The Baltic Sea as a model system for studying postglacial colonization and ecological differentiation, exemplified by the red alga Ceramium tenuicorne. Mol Ecol 11:2083-2095

Gallardo MH, Carrasco JI (1996) Genetic cohesiveness among populations of Concholepas concholepas (Gastropoda, Muricidae) in southern Chile. J Exp Mar Biol Ecol 197:237-249

Gallardo MH, Gonzalez C, Mena C, Lomovasky B, Morriconi E, Clasing E (2003) Allozymic variation in the clam genus Eurhomalea (Bivalvia: Veneriidae) along southern South American coast. Rev Chil Hist Nat 76:501-507

Galleguillos R, Troncoso L, Oyarzun C, Astorga M, Penaloza M (2000) Genetic differentiation in Chilean hake Merluccius gayi gayi (Pisces: Merlucciidae). Hydrobiologia 420: 49-54

Gomez-Uchida D, Weetman D, Hauser L, Galleguillos R, Retamal M (2003) Allozyme and AFLP analyses of genetic population structure in the hairy edible crab Cancer setosus from the Chilean coast. J Crustac Biol 23:486-494

Graham MG, Vásquez JA, Buschmann AH (2007) Global ecology of the giant kelp Macrocystis: from ecotypes to ecosystems. Oceanogr Mar Biol Annu Rev 45:39-88

Gutierrez A, Correa T, Muñoz V, Santibañez A, Marcos R, Cáceres C, Buschmann AH (2006) Farming of the giant kelp Macrocystis pyrifera in southern Chile for development of novel food products. J Appl Phycol 18:259-267

Hall TA (1999) BioEdit: a user-friendly biological sequence alignment editor and analysis program for Windows 95/ 98/NT. Nucleic Acids Symp Ser 41:95-98

Hernández-Carmona G, McHugh DJ, Arvizu-Higuera DL, Rodriguez-Montesinos YE (1998) Pilot plant scale extraction of alginate from Macrocystis pyrifera. I. Effect of preextraction treatments on yield and quality of alginate. J Appl Phycol 10:507-513

> Hernández-Carmona G, Hughes B, Graham MH (2006) Reproductive longevity of drifting kelp Macrocystis pyrifera (Phaeophyceae) in Monterey Bay, USA. J Phycol 42:1199-1207

Hewitt CD, Stouffer RJ, Broccoli AJ, Mitchell JFB, Valdes PJ (2003) The effect of ocean dynamics in a coupled GCM simulation of the Last Glacial Maximum. Clim Dyn 20: 203-218

> Himes CMT, Gallardo MH, Kenagy GJ (2008) Historical biogeography and post-glacial recolonization of South American temperate rain forest by the relictual marsupial Dromiciops gliroides. J Biogeogr 35:1415-1424

> Hoarau G, Coyer JA, Veldsink WH, Stam T, Olsen L (2007) Glacial refugia and recolonization pathways in the brown seaweed Fucus serratus. Mol Ecol 16:3606-3636

Hulton NRJ, Purves RS, McCulloch RD, Sugden DE, Bentley MJ (2002) The Last Glacial Maximum and deglaciation in southern South America. Quat Sci Rev 21:233-241

Lancellotti DA, Vásquez JA (1999) Biogeographical patterns of benthic macroinvertebrates in the south-eastern Pacific littoral. J Biogeogr 26:1001-1006

Macaya EC, Zuccarello GC (2010) DNA barcoding and genetic divergence in the giant kelp Macrocystis (Laminariales). J Phycol 46:736-742

Macaya EC, Boltaña S, Hinojosa IA, Macchiavello JE and others (2005) Presence of sporophylls in floating kelp rafts of Macrocystis spp. (Phaeophyceae) along the Chilean pacific coast. J Phycol 41:913-922

Marchelli P, Gallo L (2006) Multiple ice-refugia in a southern beech of South America as evidenced by chloroplast DNA markers. Conserv Genet 7:591-603

Martínez EA, Cárdenas L, Pinto R (2003) Recovery and genetic diversity of the intertidal kelp Lessonia nigrescens (Phaeophyceae) 20 years after El Niño 1982/83. J Phycol 39:504-508

> McCulloch RD, Bentley MJ, Purves RS, Hulton NRJ, Sugden DE, Clapperton CM (2000) Climatic inferences from glacial and palaeoecological evidence at the last glacial termination, southern South America. J Quaternary Sci 15:409-417

McKenzie PF, Bellgrove A (2008) Dispersal of Hormosira banksii (Phaeophyceae) via detached fragments: reproductive viability and longevity. J Phycol 44:1108-1115

> Meneses I, Santelices B (2000) Patterns and breaking points in the distribution of benthic algae along the temperate Pacific coast of South America. Rev Chil Hist Nat 73: $615-623$

> Muellner AN, Tremetsberger K, Stuessy T, Baeza CM (2004) Pleistocene refugia and recolonization routes in the southern Andes: insights from Hypochaeris palustris (Asteraceae, Lactuceae). Mol Ecol 14:203-212

$>$ Muhlin JF, Brawley SH (2009) Recent versus relic: discerning the genetic signature of Fucus vesiculosus (Heterokontophyta; Phaeophyceae) in the northwestern Atlantic. J Phycol 45:828-837

Muhlin JF, Engel CR, Stessel R, Weatherbee RA, Brawley SH (2008) The influence of coastal topography, circulation patterns, and rafting in structuring populations of an intertidal alga. Mol Ecol 17:1198-1210

Muraoka D, Saitoh K (2005) Identification of Undaria pinnatifida and Undaria undarioides Laminariales, Phaeophyceae using mitochondrial 23S ribosomal DNA sequences. Fish Sci 71:1365-1369

Neushul M (1971) The biology of giant kelp beds (Macrocystis) in California: The species of Macrocystis. Nova Hedwigia 32:211-222

Nikula R, Fraser CI, Spencer HG, Waters JM (2010) Circumpolar dispersal by rafting in two subantarctic kelpdwelling crustaceans. Mar Ecol Prog Ser 405:221-230

North WJ (1994) Review of Macrocystis biology. In: Akatsuka I (ed) Biology of economic algae. Academic Publishing, The Hague, p 447-527

> Provan J, Powell W, Hollingsworth PM (2001) Chloroplast microsatellites: new tools for studies in plant ecology and evolution. Trends Ecol Evol 16:142-147

Reed DC, Schroeter SC, Raimondi PT (2004) Spore supply and habitat availability as sources of recruitment limitation in the giant kelp Macrocystis pyrifera (Phaeophyceae). J Phycol 40:275-284

Reed DC, Kinlan BP, Raimondi PT, Washburn L, Gaylord B, Drake PT (2006) A metapopulation perspective on patch dynamics and connectivity of giant kelp. In: Kritzer JP, Sale PF (eds) Marine metapopulations. Academic Press, San Diego, CA, p 353-386

- Riginos C, Nachman MW (2001) Population subdivision in marine environments: the contributions of isolation by distance, discontinuous habitat, and biogeography to genetic differentiation in a blennioid fish, Axoclinus nigricaudus. Mol Ecol 10:1439-1453

Rodriguez-Serrano E, Hernandez CE, Palma RE (2008) A new record and an evaluation of the phylogenetic relationships of Abrothrix olivaceus markhami (Rodentia: Sigmodontinae). Mamm Biol 73:309-317

Rozas J, Rozas R (1995) DnaSP, DNA sequence polymorphism: an interactive program for estimating population genetics parameters from DNA sequence data. Comput Appl Biosci 11:621-625

> Ruzzante DE, Walde SJ, Gosse JC, Cussac VE, Habit E, Zemlak TS, Adams EDM (2008) Climate control on ancestral 
population dynamics: insight from Patagonian fish phylogeography. Mol Ecol 17:2234-2244

Santelices B (1980) Phytogeographic characterization of the temperate coast of Pacific South America. Phycologia 19: $1-12$

Santelices B, Meneses I (2000) A reassessment of the phytogeographic characterization of temperate Pacific South America. Rev Chil Hist Nat 73:605-614

Steinfartz S, Glaberman S, Lanterbecq D, Marquez C, Rassmann K, Caccone A (2007) Genetic impact of a severe El Niño event on Galápagos Marine Iguanas (Amblyrhynchus cristatus). PLoS ONE 2:e1285

Sunnucks P, Wilson ACC, Beheregaray LB, Zenger K, French J, Taylor AC (2000) SSCP is not so difficult: the application and utility of single-stranded conformation polymorphism in evolutionary biology and molecular ecology. Mol Ecol 9:1699-1710

Tellier F, Meynard AP, Correa JA, Faugeron S, Valero M (2009) Phylogeographic analyses of the $30^{\circ} \mathrm{S}$ south-east Pacific biogeographic transition zone establish the occurrence of a sharp genetic discontinuity in the kelp Lessonia nigrescens: vicariance or parapatry? Mol Phylogenet Evol 53:679-693

Thiel M, Gutow L (2005) The ecology of rafting in the marine environment. I. The floating substrata. Oceanogr Mar Biol Annu Rev 42:181-264

Thiel M, Macaya EC, Acuña E, Arntz WE and others (2007) The Humboldt current system of northern-central chile: oceanographic processes, ecological interactions and socioeconomic feedback. Oceanogr Mar Biol Annu Rev 45:195-344

Toro JE, Aguila PR (1996) Genetic differentiation of populations of the oyster Ostrea chilensis in southern Chile. Aquat Living Resour 9:75-78

Toro JE, Castro GC, Ojeda JA, Vergara AM (2006) Allozymic variation and differentiation in the Chilean blue mussel, Mytilus chilensis, along its natural distribution. Genet Mol Biol 29:174-179

Uwai SY, Nelson W, Neill K, Wang WD and others (2006) Genetic diversity in Undaria pinnatifida (Laminariales, Phaeophyceae) deduced from mitochondria genes origins and succession of introduced populations. Phycologia 45:687-695

van den Hoek C (1987) The possible significance of longrange dispersal for the biogeography of seaweeds.

Editorial responsibility: Philippe Borsa, Montpellier, France
Helgolander Meeresun 41:261-272

> van Oppen MJH, Olsen JL, Stam WT (1995) Genetic variation within and among North Atlantic and Baltic populations of the benthic alga Phycodrys rubens (Rhodophyta). Eur J Phycol 30:251-260

Vásquez JA (2008) Production, use and fate of Chilean brown seaweeds: resources for a sustainable fishery. J Appl Phycol 20:457-467

> Vasquez JA, Vega JMA, Buschmann AH (2006) Long term variability in the structure of kelp communities in northern Chile and the 1997-98 ENSO. J Appl Phycol 18:505-519

Vega JMA, Vásquez JA, Buschmann AH (2005) Population biology of the subtidal kelps Macrocystis integrifolia and Lessonia trabeculata (Laminariales, Phaeophyceae) in an upwelling ecosystem of northern Chile: interannual variability and El Niño 1997-1998. Rev Chil Hist Nat 78:33-50

Victoriano PF, Ortiz JC, Benavides E, Adams BJ, Sites JW Jr. (2008) Comparative phylogeography of codistributed species of Chilean Liolaemus (Squamata: Tropiduridae) from the central-southern Andean range. Mol Ecol 17: 2397-2416

Vidal R, Meneses I, Smith M (2008) Phylogeography of the genus Spongites (Corallinales, Rhodophyta) from Chile. J Phycol 44:173-182

> Voisin M, Engel CR, Viard F (2005) Differential shuffling of native genetic diversity across introduced regions in a brown alga: aquaculture vs. maritime traffic effects. Proc Natl Acad Sci USA 102:5432-5437

> Xu JW, Perez-Losada M, Jara CG, Crandall KA (2009) Pleistocene glaciation leaves deep signature on the freshwater crab Aegla alacalufi in Chilean Patagonia. Mol Ecol 18:904-918

Zemlak TS, Habit EM, Walde SJ, Battini MA, Adams EDM, Ruzzante DE (2008) Across the southern Andes on fin: glacial refugia, drainage reversals and a secondary contact zone revealed by the phylogeographical signal of Galaxias platei in Patagonia. Mol Ecol 17:5049-5061

> Zemlak T, Habit E, Walde S, Carrea C, Ruzzante D (2010) Surviving historical Patagonian landscapes and climate: molecular insights from Galaxias maculatus. BMC Evol Biol 10:67

Zuccarello GC, Lokhorst GM (2005) Molecular phylogeny of the genus Tribonema (Xanthophyceae) using rbcL gene sequence data: monophyly of morphologically simple algal species. Phycologia 44:384-392

Submitted: May 29, 2010; Accepted: October 25, 2010 Proofs received from author(s): December 4, 2010 